
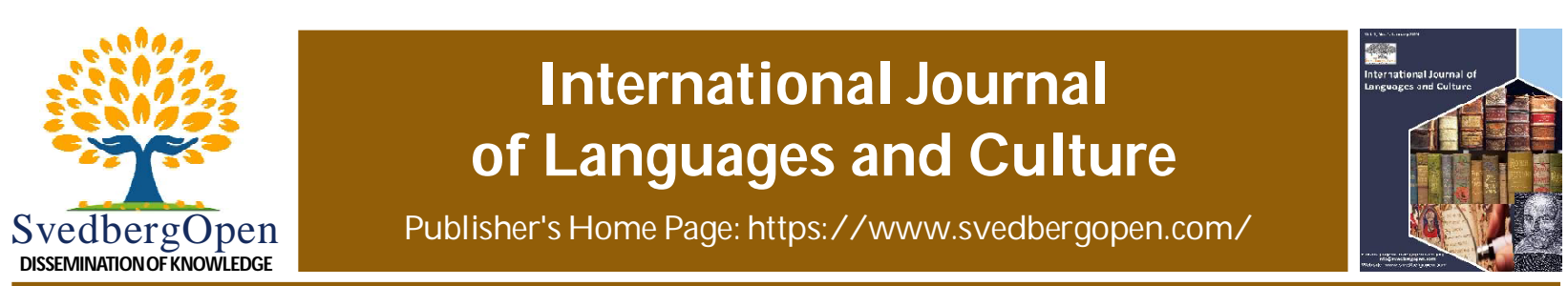

Research Paper

Open A ccess

\title{
The role of traditional songs in preserving languages of minority: The Beja case in Sudan
}

\author{
Hassan Ali Adrob ${ }^{1 *}$
}

'English language, Linguistic Lecturer and a teacher trainer at Red Sea University, Oman; Red Sea University, Sudan. E-mail: hassanadrob@yahoo.com

\section{Article Info}

Volume 1, Issue 1, March 2021

Received : 18 November 2020

Accepted : 25 January 2021

Published : 05 March 2021

doi: 10.51483/IJLC.1.1.2021.18-37

\begin{abstract}
The objective of the study was to identify the problems of languages of minority in general, and more specifically, the Beja language in Sudan. In order to achieve this goal, a question of how to preserve the languages of minority was raised. This study responds to (Morin, 1997), recommendation about preserving Bedawiet language; therefore, this research looked up for literature to answer the question. Surprisingly, very limited resources were found and collecting oral data was the only option that (Morin, 1997), referred to. Luckily, some active Beja poets have already uploaded songs and poems in order to preserve the culture and Beja heritage. Therefore, the research contacted with them and translated the songs into English and an IPA is used to script the Bedawiet sounds. As the collected data was categorized into two periods; the descriptive analytical approach was implemented to address the question of languages dying out. The data summary concludes that traditional songs had average of lower than 2 borrowed words, whereas in modern songs have exceeded $45 \%$ in one poem (Poem, 16). A volunteering panel that judged the songs had resulted in reducing the borrowed words in the modern period as well. Based on these findings, the study recommends reactivating the panel's tasks and teaching these songs to children at schools. Teaching Bedawiet syllable is available at the Beja Cultural Studies Centre at Red Sea University, so the study recommends training the teachers in the centre and involving parents in the processes of language maintaining.
\end{abstract}

Keywords: Traditional Beja songs, Beja minority, preserving languages, Bedawiet poems and literature, Bedawiet heritage in Sudan

(C) 2021 International Journal of Languages and Culture. This is an open access article under the CC BY license (https://creativecommons.org/licenses/by/4.0/), which permits unrestricted use, distribution, and reproduction in any medium, provided you give appropriate credit to the original author(s) and the source, provide a link to the Creative Commons license, and indicate if changes were made.

\section{Introduction}

Linguists believe that many languages will disappear very soon as the result of globalization and the generation of immigrants who grew up in non-native countries and as a result, they shift to the languages of hosting countries, (Chauvot, 2016). Chauvot also thinks that three billion people speak 20 languages, whereas 7,000 languages around the world are at risk. Beja minority, who are the inhabitant of the North-Eastern part of Sudan, Egypt and Eretria for 4000 years, speak a language called Bedawiet, (Beja, 2018). Today, the community in the region is approximately 2.2 million, (Dahl, 1991, p. 1). The language has three dialects, -two in the north and one in the south,--. Arabic is spoken in the region besides other Sudanese local languages and dialects.

\footnotetext{
* Corresponding author: Hassan Ali Adrob, English language, Linguistic Lecturer and a teacher trainer at Red Sea University,
} Oman; Red Sea University, Sudan. E-mail: hassanadrob@yahoo.com 
Bedawiet speaking children are taught English at school as a second official language, too. These languages overlap as they are spoken in one narrow coastal line cities on the Red Sea. Therefore, Bedawiet speaking children have been affected by the complex linguistic phenomenon that challenges learners; as well as Bedawiet as a language that has also been absorbed in the other languages.

Together with other local languages, Bedawiet is taught as an official language to minorities in one of the neighboring countries, therefore, the language has obtained recognition and their language rights are implemented officially since it was clearly stated and documented in the country in 2010, (UNICEF, 2017).

Using the language in the media was a possible option in Sudan, especially on the regional radio or TV channels in Red Sea and Kassala States. However, the limited time that was allocated only for educational programs did not serve audiences because the programs were broadcasted when the targeted populations were either at schools or work, which deprived the intended audience not to have access to it. The newspaper was considered as an unreliable source as a recent, (UNHCR, 2018) report rates illiteracy among the Beja nation between 50 and $90 \%$.

Many studies, in summaries, concluded that Bedawiet have been borrowing a great number of words from Arabic and other neighboring languages, which has resulted in changing the phonological structure of words, meaning and morphology, (Hudson, 1964).

As Arabic and English language are the dominant languages in the region, which are used in education and the internet, people only communicate with these languages because Bedawiet is not a written language. Thus, the community, in general, is found lacking the cultural features which are related to the natural life of the citizens.

Due to the diminution of the value of the language in children's life and the limited involvement in their everyday activities, parents have reduced using Bedawiet frequently even at home. In addition, Bedawiet that is spoken in cities has also significantly changed. In light of this, there is a need to maintain its vital objective because the sound of many words has been changed according to the comprehensive borrowing from Arabic (Adrob, 2020).

This study is based on a recommendation of an article titled, "Mimetic Traditions in Beja Poetry from Sudan", by (Morin, 1997) on which he prioritizes the necessity of studying and understanding the sociolinguistic situation that has influenced the spoken languages. He adds to that, the representation of multilingual Beja in the area.

\section{Research in Beja language songs and poetry}

In the literature, there are only two books and four papers have tackled important topics of Beja poetry during the last century. The first book that elicited some historical events from poetry is titled, "From the Beja History". It was written in Arabic by Ohaj M (2008). The writer used English letters to script the poems. Morin (1997) mentioned that in his study about Beja culture and heritage.

The second important source is "The Beja Camels", which was written by Osheik (2012). In his book, he mentions specifically in chapter 12, varied poems describing Beja camels. The book is a useful source as it contains a huge collection of poems in different periods from many resources. Although it is written in Arabic, the author has also scripted the lines of poems in English, too.

Morin (1997) commented on the study of Roper (1928), which was referred to the unknown Beja oral poetry. He exemplifies by writing a four lines poem called/habiet/ in Bedawiet with a translation in English. This style of poetry remains among the current poets who aim to keep the culture and heritage of Beja. The style of four lines is called /fædiggir-meit/, that literally means "of four heads" as the below example shows.

\begin{tabular}{|l|l|}
\hline Bedawiet & Meaning In English \\
\hline Ite śankéte bās' âbik & (Contrary to those) with clothes caught \\
\hline yi híndi te tâgeyetē & In the thorn bushes, and also hats, \\
\hline u r' ád at' aféyā bâde hin dāa & Who died protecting their family \\
\hline dáwit téteb abādenen & He, he has forgotten his relatives \\
\hline
\end{tabular}

In a total of 18 words poem, only one word is borrowed from Arabic. The only Arabic borrowed word is /tageyete/ in line 2, which means "a hat" in Arabic. This was clear evidence of a low frequency of Arabic words in Beja at that time. Later the Bedawiet speaking author and historian, Mohammed Adroub Ohaj wrote the same poem in two lines instead of four. Morin (1997) believes that writing the poetry into two or four lines is one of the characteristics of the Arabic poem which means the domination of the culture of the Arabs in Beja. 
Vahove (2006) highlighted the influence of Arabic culture on Beja, which he believes poetry is the only way to preserve the languages. However, he claimed that the language of Beja indicates prestige for the natives who proudly speak it; it is still a subject to missing some basic style and changing certain principle features of Beja culture.

Wedekind and Mahmoud (2008) conducted another essential study aimed at comparing the lexical differences in four Bedawiet dialects in the region. They used old stories and a song written about a well-known Beja hero who fought the Turkish leader Mumtaz Basha in Sawakin. The song was composed in the late 1880s and currently sung in different dialects in the region, which slightly distorts the original meaning and the taste of Beja Culture. Below is the song in five lines with translation in English.

\begin{tabular}{|l|l|}
\hline Bedawiet & \multicolumn{1}{|c|}{ Meaning in English } \\
\hline $\begin{array}{l}\text { Oor whalgi shuuraana hamiinaay kallafaana. } \\
\text { boy the-tall thin bitter not-persuade }\end{array}$ & Don't try to intimidate a small boy (he won't accept it) \\
\hline Oor tookwa kiidaanin boy the-sister not-insults & A boy won't insult his sister \\
\hline isaniida kiimeelbaab the-brother-to not-wear & he won't wear his dagger to confront his own people \\
\hline Sagiit gabiileetiida far tribes-to & only against far-away borders \\
\hline B'adhdhooh raboobsiini. sword unsheathe & he will unsheathe a sword \\
\hline
\end{tabular}

In the above song, the total number of words is 22; only one word is of Arabic origin. The word is /gabiileetiida/, which is the Arabic word -"tribe"-. Bedawiet has an equal term for the word "tribe"; however, the writer meant to use the word/gabiileetiida/, as it rhymes with the lines.

Obviously, the song conveys a strong message, and the writer was able to communicate the messages through Bedawiet language with an extremely limited number of borrowed words. However, the song has been sung for more than 140 years, it still maintains the same original lexis and structure. This clearly indicates that the necessity of art, in general, and more specifically, the songs in preserving the languages of minorities.

Vanhove and Taher (2018) discussed the existence of women's songs in the Beja literature, which were recited and socialized in groups by greeting each other as well as dealing with historical themes. This research highlights some poems in the coming sections. For example, the two authors referred to the famous song, "Sinkat", in which three lines were describing the features of the beloved character.

\begin{tabular}{|l|l|}
\hline Bedawiet & \multicolumn{1}{|c|}{ Meaning in English } \\
\hline$i=$ talha.j $t=$. ambalo. $j$ ha. $m-a=b$ & The brown color covering the lips, \\
\hline e.t $k$ w ile. $=t=$ e.t nafs- $i .=t=a=i t$ & Since the teeth are brightly white' \\
\hline$j a d a .=$ it fu.te.ti.t so.t $g$ wala.l & $\begin{array}{l}\text { (The skin) is beautiful like a young autumnal sprout } \\
\text { (Hamid Ahmed 2005) }\end{array}$ \\
\hline
\end{tabular}

In this part of the song, "Sinkat", pointed out that there are about14 words and some pronouns. As it is a traditional song, there is only one word borrowed from Arabic. The word is in line one /ha.m-a=b/, which means, -"covering"-. Again, the low frequency of Arabic words in the traditional songs is a key feature; therefore using poetry can keep languages from being extinct and obsolete.

One of the most important themes of Beja songs was praising the camels. As the Beja were desert dwellers, camels are at the heart of their culture, on which their lives completely depended on. They took care of it and a huge number of praising songs described the camel's indispensable existence in their life in themes such as speed, beauty, height and prestige. Osheik (2012) believes that a camel was a source and sign of wealth in the Beja community.

Vanhove and Taher (2018) exemplify the importance of camel in Beja life with the below line from a traditional song. 


\begin{tabular}{|l|c|}
\hline Bedawiet & Meaning in English \\
\hline$d e: f a-j$ i=lagad $b a .=d a . s-a j$ & Without putting a leg in the gate. \\
\hline
\end{tabular}

\section{Methodology}

The study describes and analyses the role of traditional poetry and songs in preserving Bedawiet language and how to maintain the spoken languages of those who live in cities in the Beja region. It was obviously clear that when two or more languages are spoken in one geographical area, they overlap in a way which allows the dominant languages to have an effect on the others.

Arabic is considered as the first communication language in the region; therefore many Sudanese who live among the Beja speak their own local languages which are totally different from Bedawiet; as a result, the Beja people are unconsciously found themselves speaking in Arabic. The second official language which is taught in school is English. These two official languages are much exposed to the locals; in addition, they are widely used in surfing the internet and official languages as well.

This study focuses on analyzing traditional poems and comparing them to modern songs to realize how the Beja language, Bedawiet, influenced other neighboring languages. The study also aims at finding ways to preserve the languages of minorities in Sudan and probably the rest of the world with similar cases.

Only four important studies are now available in the literature, besides the two Arabic books which were written by Bedawiet speaking authors. Since the books and studies, about Beja poetry and songs, have limited themes, the research collects the data from the oral avail recorded audio and video on YouTube. The study has also contacted Osheik Mohammed, whose interests are mainly in collecting and gathering soft recordings and hard items of the Beja culture to preserve the heritage.

Furthermore, Osheik, besides providing the research with a huge collection of traditional songs and poetry, he added a list of what he called women's work (see Appendix 2). In addition, he arranged some poems with unknown writers, which were considered in the study under the category of women as they were assumed to have hidden their names according to the traditions and customs of Beja at that time.

The collected data were classified according to the period when the songs were composed and briefly the themes were discussed. To achieve the main objective of the study, the traditional songs are placed under one category. The contemporary songs were put in another category, so that the analysis of these songs can signify how the Beja language has been changing throughout the period from 1800s up to 2020 in order to suggest solutions for preserving it and stating relevant recommendations.

This researcher has scripted these audio and video files with the support of Osheik Mohammed and translated them into English. For the benefit of readers, an IPA style was implemented to write the sounds of Beja songs. Some sounds which were not available in English were listed in Appendix (1) at the end of the study. The first four poems were written as they were found in their resources.

\section{Analysis and Findings}

Basically, the data collected for this study were gathered from two reliable resources. The first one was the four important papers published between 1997 and 2018 and the two books which were written in Arabic by Bedawiet speaking authors; however, there were only a few poems that benefited from these resources. The second source was the oral Beja literature.

As it was mentioned earlier, there is a good collection of oral Beja poetry and songs on YouTube. These poems were put together and categorized to assist the objective of the study. Then in the analysis stages, an examination of the Arabic words in the Beja songs was made, in the period from 1800 up to the present, in order to answer the problematic research questions, which was primarily about preserving the languages of minorities.

\subsection{Beja popular songs and poetry}

Bedawiet has rich oral traditional and modern songs and poems which are searchable by Bedawiet speakers; however, due to some major technical and logistical reasons they have an extremely limited access to them. Therefore, this study peers at drawing the locals' attention to the online available traditional songs as they covered different themes which are reliable today. Until recently, Beja society classified poets and singers notoriety and as a result, they were refused in the community. 
According to customary and social rules, it was natural to get songs with unknown writers. In order to overcome this problem, singers used to deliver songs in the family occasions and gatherings and the public repeated these songs years until they familiarize themselves with the songs and in the next celebrations they enjoyed practicing the new songs. Generally, poets used to describe the desert life, camels and the seasonal gatherings besides their battles, courageous words and victory when they were fighting for their land and their deprived rights.

Since the middle of the last centuries, some singers have contributed to Beja songs. Famous names were sung in public and the Sudanese National Radio and TV Corporation Library has records of these songs which were sung live in the 1960s. Some of these songs were completely Arabized to convey the message to the country rather than the local community. For example, the famous song, -“Al-Ja-bana"-, is a traditional Beja song, but there is not a single word from the Bedawiet language.

\begin{tabular}{|l|c|}
\hline Bedawiet & Meaning In English \\
\hline /sau-wi a-dzəbənə jæ bu-nia/ & Make the coffee oh my son, \\
/fi: đi-li-ada-hæx-wial & in the shadow of the forenoon (time). \\
& \\
\hline
\end{tabular}

This song is well-known in Sudan and it is sung now by a famous Sudanese band called-"Agd-Al-Jalaad"-. In this line, the poet detailed some key features of Beja culture which was conveyed in Arabic because Sudanese were required to understand each other's culture as it was sung in the period of Sudan's independence day.

\subsection{Traditional Beja Poetry and Songs (1800-1900)}

There are a few records available in the literature, which show some samples of the early Beja typical poetry without discussing the situation when the poems were written; however, the themes and names of the characters indicated the periods. For example, in some of the poems, names such as Mumtaz Basha and the English People who settled in city Sawakin,-a city on the Red Sea-, were mentioned. Those poets were living in the $19^{\text {th }}$ century, whose work of art marked Beja Culture as remarkable and colorful in many cultural and heritage aspects.

Some writers had discussed incidents that occurred earlier than when the Turkish Empire controlled Sudan. Consequently, in this study the period of early poets was extended to 100 years. The poetry was characterized by the simplistic; and the poets covered many important issues such as celebrations, travelling, camels, coffee gatherings, unique natural beauty, happy and sad occasions (Osheik, 2012). Rhyming songs helped the public to keep them orally for more than 200 years. Below are some samples of the work of art and literature.

The first poem (1) was written by a great poet in his time. His name is Abu Ali Geelay Our. He was a wise, famous leader and poet. He lived in the period of Madhdi in Sudan. His poems were characterized by giving advice to people in order to live peacefully and the need to survive without quarrelling with each other. The poem is in four lines.

\begin{tabular}{|l|l|}
\hline \multicolumn{2}{|c|}{ Geelay Our - Poem (1) } \\
\hline Line & Meaning \\
\hline leinda jam-fadina mikri:b/ & The men who don't agree in opinion, \\
\hline /tiga-dijia bakæn gari:-mi:b/ & those who don't know what's going on, \\
\hline /w?a-Su eit-fi:d/ & the enemy ridicules them, (and) \\
\hline It?ajaj ti:t-lis/ & their relationship deceives. \\
\hline
\end{tabular}

The total number of words in this poem (1) is 12. They are all Bedawiet words. It supposes the influence of Arabic on Bedawiet was zero. At that time, the poets only used lexis from the Bedawiet language to express their feelings.

The poem below (2), which was also written by Geelay Our is written in six lines of 14 words. 13 of these words are from Bedawiet. Only one word in line 5 is in Arabic. The word is an adjective, -/i $\square$ ah-li:b/-, which means, - "illiterate". 


\begin{tabular}{|l|l|}
\hline \multicolumn{2}{|c|}{ Geelay Our - Poem (2) } \\
\hline Line & Meaning \\
\hline$/$ / $æ$-ji:niat kiti bihi:wu:k/ & Kindness is nothing if you don't feel it, \\
\hline /tau-mæg bi:-sah-ri:-wu:k/ & if he doesn't want to harm you, \\
\hline /u:si bi-Su: m?ajeib augi-n?a/ & the heart who doesn't accept advice, \\
\hline /akræt wæsanait-ti:b/ & flooded with doubt, \\
\hline /itaku:k idsah-li:b hælei-jæb/ & your relative who unconsciously demons,(you) \\
\hline /jaf amæg dah-ri:b/ & this must be of bad luck. \\
\hline
\end{tabular}

The second poet is Ali Haujer Our, poem (3). He lived in the period of Mahdi in Sudan in the last quarter of the $19^{\text {th }}$ Century. His poetry marked the significance of wisdom in real life, and he wrote about the glory of Beja fighters as well as praising knights for their victorious battles.

\begin{tabular}{|c|c|}
\hline \multicolumn{2}{|c|}{ Ali Haujer Our - Poem (3) } \\
\hline Line & Meaning \\
\hline /dalu: tæk amæg-iwar- ju:k/ & If a close man treats you badly, and \\
\hline /sagi tæk d\}æba-ria-jei-tu:k/ & a strange man be nice to you, \\
\hline /tu-fibu:b udग:rว kinæb tibərihən/ & does this kindness have owners, \\
\hline Itu-mag-nia ləm-mi:-deik/ & if you have habitually wrong behaviour? \\
\hline
\end{tabular}

The poem (3) consists of 14 words in four lines. It is mostly produced in Bedawiet language; although only one word in line 2 is from the Arabic origin. The word is a noun, /dzæba-ria/, which means, "courtesy".

The fourth poem is written by Musa Atmaan (Gidif). He was famous in his period. He also lived in the Mahdi's period in Sudan. He was a bit outgoing by tackling topics such as love at that time and passion by then.

\begin{tabular}{|l|l|}
\hline \multicolumn{2}{|l|}{ Musa Atmaan - Poem (4) } \\
\hline Line & Meaning \\
\hline /dauri-kat eifein alja- kæt mAf-rania-teit/ & There were many (who)were prettier than them physically and lineage, (and) \\
\hline$/$ tibæn- $\int$ J:fi u:-dab i:mæn t?ama/ & their gravity and good manner, etiquette, \\
\hline$/ k i:-f i: n$ aliat $r /$ & (however), nobody can equal (Ali's daughter) manner or gentleness. \\
\hline
\end{tabular}

In a total of 13 words in three lines, Musa Atmaan used only two words from the Arabic origin in the poem (4). The two words fully adapt to Bedawie grammar rules. The words are in line 2 and 3 . One of them is $/ u:-d\lceil/$, which means "politeness". The second word which is in line 3 is a name.

A name cannot be given in Bedawie unless it is a nickname or an adjective. As Beja are all Muslims, they get their names from Islam and traditional names that have different meanings in Bedawie, so in order to say “Ali's daughter", he uses the Arabic origin words, /aliat $\mathrm{Jr} /$.

The poet Hassan Auyeet usually describes the camel and the difficulties he used to face while he was travelling in the desert. As he was in one of the journeys back home, he saw his (she) camel sweating from the sun's heat. He had to praise the camel and show admiration and appreciation to complete the journey in these four lines. The poem (5) was written in this situation as he was proud of his (she) camel in a long journey. 


\begin{tabular}{|l|l|}
\hline \multicolumn{2}{|l|}{ Hassan Auyeet - Poem (5) } \\
\hline Line & Meaning \\
\hline /dhani tæk mbdali:b dai:ni/ & Whoever alive, can be changeable, \\
\hline /dor harba-mi:n/ & once (he) might damage his land, \\
\hline /wei- lætuj w?aji- ku:ra- meh/ & "Eilat",-(a name of his (she) camel)-, that its saddle can be heard from distances, \\
\hline /tu- lalgi hai anasjei- took & be ready to get through the Wadi "Tulqwi-jai", that takes me to my land. \\
\hline
\end{tabular}

In a fourteen words poem and four lines, Hassan Auyeet used only two words from the Arabic origin in the poem (5). The two words are adjectives, /mbdali:b/in line one and/harba-mi/in line 2. The meaning of the words are,-"changeable" and "destroy"-, respectively.

Musa Nofil was not only a poet, but he was also a brave fighter. His poems were mainly about battlefields he was involved in, so he showed pride in himself and his tribe as he was fighting against the colonists who occupied his land.

\begin{tabular}{|c|c|}
\hline \multicolumn{2}{|r|}{ Musa Nofil - Poem (6) } \\
\hline Line & Meaning \\
\hline /ar-tei-ga wa-mu:d כnfi:Shabəkæb/ & I am proud of my "Arteiga" (tribe) and much more "Onfeesh", (a clan), \\
\hline /keif-ri:b sım-m?amti gi:gi nıfl-aur kaja -wædial & it is impossible to be said that "Nafil's son" died humble under a non-Muslim. \\
\hline
\end{tabular}

The poem (6) consists of 10 words in 3 lines. Musa Nofil used only one word from Arabic. The word is a noun in line one, /wәтu:d/, which is meaning, - "pillar"-. The word is used figuratively to express the height of his people.-/ar-tei-ga/.

The general observation of the six poems above, which were mostly written in a similar environment and time, was the very limited number of Arabic words used in the poetry. The maximum number of words used in these poems was 2 words. However, the rest appeared only in one Arabic word. These words were either nouns or adjectives.

Below is another set of poetry of anonymous writers. It was categorized as traditional poetry because of the writers' themes and the low number of Arabic words in each stanza.

\subsection{Traditional poems and songs with unknown writer}

Beja society previously was marked as a self-centered community until the last two centuries. However, Ibni- Battuta visited Sawakin on the Red Sea in the $14^{\text {th }}$ Century; he only documented the trade and social life, which he greatly admired and reflected on them. The middle of the $19^{\text {th }}$ Century was considered as the first time, in which Beja poetry started being recognized, documented and recorded as one of the literary science elements.

It was normal to get so many songs with unknown writers since the society used to refuse poets and singers socially. In addition, it was believed that the anonymous songs were written by women who hid their names according to the traditions and customs of these communities of that time not allowing them to express their talents publicly.

The songs were sung by women in groups during special occasions and they inherited from one generation to the other. Thus, the Beja literature has a number of songs with unknown writers. This research will mainly focus on only selecting a few examples; however, further investigations in this type of poetry are needed in future.

\begin{tabular}{|c|c|}
\hline \multicolumn{2}{|r|}{ Poem (7) } \\
\hline Line & Meaning \\
\hline /u-fh-mכ: gadı bæ-tahial & Those (who) try to achieve their aims in life without understanding, \\
\hline /u-dzh-li:b bæməki:ru:k/ & who doesn't consult on (what) he doesn't know, \\
\hline lu:tæk ubæsia-i:s bæ-səhji:sal & the man (who) neither benefits himself nor others, \\
\hline /tahau- jeiti dæ-ji:b hami:bu/ & is a person (who) hardly deals with difficult situations. \\
\hline
\end{tabular}


In poem (7), there are four lines and 13 words. Only two words are nouns from Arabic. $/ u-f h m s /$ and $/ u$ - $d$ z $h$-li/, in line 1 and 2 are antonyms meaning, -"perceive"- and, -"ignorant"-. The poem number (8) below was also written by an unknown writer. It was about the customs and good practices of Beja people. The song is now famous with practical parables and wisdom.

\begin{tabular}{|l|l|}
\hline \multicolumn{2}{|c|}{ Poem (8) } \\
\hline Line & Meaning \\
\hline leində imh-gi-gil badi:n/ & The men (who) can't be separated, \\
\hline Itau-na ti-du:m- əni:ti:b/ & (conflicting) with nothing, \\
\hline /w?adim wæe afda-li:n/ & it is better to quit (their relationship) quietly than to argue unnecessarily. \\
\hline
\end{tabular}

Poem (8) consists of three lines and 10 words. The only Arabic word in line 3 is /afd, $a$ - li/, which means "better". The last poem in this group is (9). It is written in three lines and 14 words. None of the words of this group are from Arabic origin.

\begin{tabular}{|l|l|}
\hline \multicolumn{2}{|c|}{ Poem (9) } \\
\hline Line & Meaning \\
\hline Itær-bə imaldadi:b bei-rei- hən?/ & Do mountains move on the ground, \\
\hline Itæbri jeina wahsæ-li:?/ & is it possible to pull the skies, (with stripes), \\
\hline Iautæk aumæg idabu bad-dali:n/ & (so) it is impossible to change a quick-temper, \\
\hline Itu:jat au-dəhia tif-mıda- di/ & death (itself) will separate people (forever). \\
\hline
\end{tabular}

The section focuses on providing detailed examples of traditional Beja songs which are currently sung, but nobody knows the poets. This paper discusses three examples and concludes as follows. The poems are mostly containing four lines in a total average of 13 words. No single poem has more than 2 words, (nouns or adjective)-, from Arabic which confirms the low occurrence of Arabic words in Beja poetry in the $19^{\text {th }}$ Century.

\subsection{Traditional poems and songs written by women}

There is no doubt that women have greatly contributed to the Beja literature. They praise their brothers and parents. Some were proud of their parents; therefore they sang and danced on the various family occasions, communal and annual celebrations. One of the most common themes in the last two centuries was glorifying battles and women enthusing Beja fighters against the new settlers on the land.

Both poems (10) and (11) included two or three lines. Each one has an average of 11 words. Together, there is only one word from Arabic in each of the poems. In poem 10 the word is adjective, /ifæ-ll, in line 1 and it means, -"good omen"-; whereas in poem (11), the word is also an adjective, /i: $m a /$, in line 3 and it means, -"believe"-.

\begin{tabular}{|l|l|}
\hline \multicolumn{2}{|c|}{ Poem (10) } \\
\hline Line & Meaning \\
\hline /au-tæk imi:mafu ga:lu ifæ-læ gwi-dæba/ & $\begin{array}{l}\text { The man (whoever is) regardless of his background is buried once and for } \\
\text { all, but he can have (a big) amount of omens, }\end{array}$ \\
\hline $\begin{array}{l}\text { /ba-fu:-ki:ta-ma di:-tว:-k hi-nin } \\
\text { au-raun- ti-kat-jei- } k\end{array}$ & $\begin{array}{l}\text { (so), don't hesitate to rout (in the battle), if you } \\
\text { are our son. }\end{array}$ \\
\hline
\end{tabular}




\begin{tabular}{|l|l|}
\hline \multicolumn{2}{|c|}{ Poem (11) } \\
\hline Line & Meaning \\
\hline /tær-bə titageig gir-mait-wa/ & The mountains (those) with high summits, \\
\hline /tæbrifJ:t anu:t-wa/ & (and), the skies (constructed) without poles, \\
\hline /u-kwæ- sa-nia i-ma-ni:n tehe-neik tot-tว:na dili:nu/ & they remain evident of the greatest Creator if someone believes in God;. \\
\hline
\end{tabular}

\subsection{Modern poems and songs (1900-2020)}

Beja modern literature as well as the traditional songs and poems are not recorded in books, but having recorded them in cassette and CDs encouraged fans of literature to reproduce them. The diligence, dedication and initiation of Osheik Mohammed by uploading these audio and video files on the internet as a personal contribution have supported in preserving the culture and heritage of Beja. Osheik is a young Beja poet who is based in Qatar and Sudan. This research has communicated with Osheik via Abdullah Adrob who is on his contact list on Facebook. Account: https:// www.facebook.com/adroobhuaan.

\begin{tabular}{|l|l|}
\hline \multicolumn{2}{|c|}{ Osheik - Poem (12) } \\
\hline Line & Meaning \\
\hline /mag-jæj-ti: kəri:-fu:k tæk/ & The person who is ready to face the evil, \\
\hline Itaufbi gam-ti:t idæ-jə/ & (and), (he) ignores your respect, \\
\hline Iu:m-din fil-sæt i:-bəh-ri:n-hən/ & like the one (who) searches for existing ways, \\
\hline Itu:-jat hai tit-ha-ri:-beik/ & if he can escape from death. \\
\hline
\end{tabular}

Osheik is a skillful computer engineer; therefore, he contextualized the traditional songs by creating video clips in order to explain the meanings to the public. In addition, he wrote the script of the songs on the videos,-in Arabic-, so that non-native Bedawiet can identify the original culture of the Beja nation. The below songs are his own contributions to the literature:

Osheik, as a fan of the traditional songs and poems of Beja, he followed the same style by keeping the four lines and minimizing the number of Arabic words in his poems. In poem number (12), his message was sent in 13 words. He did not use even one word from Arabic origin although he is a modern poet. In order to reform the community and preserve the language and culture, he uses comprehensible terms expressing the situations.

As an immigrant, the poet sometimes feels homesick, so in the below song he described his hometown Port Sudan in poem (13) in four lines and 13 words. He uses only one word from Arabic origin which is in line one, /tzhdra, meaning, "attendees".

\begin{tabular}{|l|l|}
\hline \multicolumn{2}{|l|}{ Poem (13) } \\
\hline Line & Meaning \\
\hline /təhdra tuli:l beira/ & Yelling women, (as well as) \\
\hline /hadri ti-kamt kuæl.-li:b/ & camel racing, \\
\hline /b?a- ru:t tut ti-dJ :-bæti:t/ & Port Sudan as a bride, \\
\hline /wæfaq tok-lu:l hai bæn-qw-sær-jeik/ & is preferred to me (than) other cities. \\
\hline
\end{tabular}

In poem (14), Osheik showed another style of modern Beja writer. He wrote freely to express his feelings. This time he used some words originally Arabic as the other poets of his time do; however, he maintained the four lines style. 


\begin{tabular}{|c|c|}
\hline \multicolumn{2}{|c|}{ Osheik - Poem (14) } \\
\hline Line & Meaning \\
\hline /tu-kə-næn in-d̦iwa-areit fau-jæj-tu/ & The knowledge is the grant of men, \\
\hline /wi-lim if-ha-mi sal-mi:- ju:k/ & if they can understand it fully, \\
\hline /u:- ḑhl- au-m-d़han hal-kanæbu/ & illiteracy destroys life, \\
\hline$/ t i-n i:-j a$ geib ti-sah-dJ:d-jeik/ & if it is followed by bad faith \\
\hline
\end{tabular}

From the12 words, in four lines, Osheik wrote six words from Arabic in poem (14). Four of them are nouns and there are 2 adjectives. In line 2, there are 3 words, /wi-limi/, /if-hə.-mi/, and /sal-mi/.. These words mean, "knowledge", "understand" and "peace", respectively. Whereas in line 3 the Arabic words are, / u:- $d_{3} h l /$ and /hal-kənæbu/; meaning "ignorant" and "damage"; in addition to a word in line 4,/ti-ni:-ja/, which means, "Attention".

The poem (15) "Audab" is written by Mohammed Taher Oshake and translated into Arabic and uploaded on Facebook on October $28^{\text {th }}, 2019$ by Adroob Huaan. It is sung by the well-known Beja singer Mohammed Al-Badri. This research only selected the first four lines that benefit the study.

\begin{tabular}{|c|c|}
\hline \multicolumn{2}{|c|}{ Mohammed Taher Oshake-Poem (15) } \\
\hline Line & Meaning \\
\hline /u:-dab i-d?əm-mәгәі bæb-dæl/ & Respect can't be replaced, \\
\hline /dhJ:-si bær-la-wiet kal-ma/ & (with) words hidden in liver, \\
\hline /whia ku:ram-ti-jeik u:f-bu:b/ & bending shyly worth a lot, \\
\hline /u:d-bia ?al-ia la-mi:di:-wa/ & (and) normalizing politeness is unachievable \\
\hline
\end{tabular}

As the song "Audab" is recently sung, the number of Arabic words is a bit higher than other poems. In the four selected lines, there are 11 words from which four are originally Arabic. There are two words in line one are, $/ u$ :-dab/ and/bæb-dæl/ and they mean, -"politeness"-, -"replaced"- whereas in line 4 the words are, /u:d-bia/ and /?al-ia/, meaning, -"polite"-, and -“costly"-.

The last song "Far-saba", is widely spread in the region and it is sung by many famous singers in the Beja land as well as famous bands in the capital city such as "Hadia Band". It was written by Mohammed Mahmoud and the research found it translated into Arabic on YouTube by Adroob Huaan.

\begin{tabular}{|c|c|}
\hline \multicolumn{2}{|c|}{ Mohammed Mahmoud - Poem (16) } \\
\hline Line & Meaning \\
\hline /fær-sæb hagi:-gæti:b ग-bวi l?ว-mei bæd-digia/ & We are real knights (the Beja) who never escape when blood pours, (and) \\
\hline / ग-mæg jakin-jei-tia sa-ba-rJit ka-fæ-lm-na/ & when war starts, running out (from the battle) is not our habit, \\
\hline / J-dia itr-mu:-ma $æ$-fæl r-dæ-mei-nei-k/ & contribution, patients and good omen are our practices, \\
\hline / J-di:n fa-gi:r-jeiba J-slif h-dia-jei-ba/ & in religion (we) are religious and in treatment (we) treats in good omen \\
\hline /hedæb ti-kJ-lia-ti:b fær-sæb ga-bæ-jl-teibal & (we) are leaders and wise (by nature) and the nights among tribes \\
\hline
\end{tabular}

The song is in five lines and a total number of 21 words. The Arabic words in this poem are 10 . This is why many nonBedawiet singers sing the song. The Arabic words in the poem are highlighted bold in the lines. 


\subsection{Category (1) from 1800 s to 1900}

The Table 1 provides detailed information about the traditional poems from 1 to 6 . It includes the period from 1800 s to 1900. The average number of Arabic words in each poem was only 1 word at $89.6 \%$.

\begin{tabular}{|c|c|c|c|c|}
\hline \multicolumn{5}{|c|}{ Table 1: Traditional poems (1800s-1900) } \\
\hline Poem & Total number of words & Bedawiet & Arabic & Percentage \\
\hline 1 & 12 & 13 & 0 & 100 \\
\hline 2 & 14 & 13 & 1 & 92.9 \\
\hline 3 & 14 & 12 & 2 & 85.7 \\
\hline 4 & 13 & 12 & 2 & 85.7 \\
\hline 5 & 14 & 12 & 1 & 88.9 \\
\hline 6 & 10 & 9 & 1 & 89.6 \\
\hline Average & 13 & 12 & & \\
\hline
\end{tabular}

Table 2 shows the average number of poems written by unknown writers or women. In an average of 12 words' poems, there was only one word originally from Arabic that gives a percentage of $91 \%$ of Bedawiet lexis in each poem.

\begin{tabular}{|c|c|c|c|c|}
\hline \multicolumn{5}{|c|}{ Table 2: Unknown writers and women's poems (1800s-1900) } \\
\hline Poem & Total number of words & Bedawiet & Arabic & Percentage \\
\hline 7 & 13 & 11 & 2 & 84.6 \\
\hline 8 & 10 & 9 & 1 & 88.9 \\
\hline 9 & 14 & 14 & 0 & 90.9 \\
\hline 10 & 11 & 10 & 1 & 90.5 \\
\hline 11 & 11 & 10 & 1 & 91 \\
\hline
\end{tabular}

\subsection{Category (2) from 1900 to2020}

This period witnessed the establishment of the new country (Sudan) and the need for unity was the key objective of the leaders. It was the time when the civil education launched besides the Quranic Schools, -"schools of teaching the Holy Book of Islam"-, which were established in villages.

It was also the time when non-Arabic speakers were involved in jobs such as teaching in the regions. Thus, reflects the appearance of Arabic lexis in their work. The table below shows percentages of poems 12 to 16 and it is divided into two sections as the features of the songs are varied.

Modern poetry has different percentages of Arabic words used in the poems. Starting with poems 12 and 13 which display a high number of Bedawiet words with almost 93\%; this explains the period when a panel of volunteers in Beja Club judged the work of poets before it was presented to the public. Therefore, writers carefully chose the word so that they could get their poems approved for publishing.

On the other hand, poems 14 to 16 show a proportion of Arabic words exceeded 35\%. This is the real situation of Arabic words in Beja language today. The poets have selected words from the everyday language of the population in the Beja region to express the situations. For example, poem 16 had almost $50 \%$ of the words are of Arabic origin which is very high and the same is true for poems 14 and 15 which together reach just under $30 \%$. 


\begin{tabular}{|l|c|c|c|c|}
\hline \multicolumn{5}{|c|}{ Table 3: Poems written by modern writer (1900-2020) } \\
\hline Poem & Total number of words & Bedawiet & Arabic & Percentage \\
\hline 12 & 13 & 12 & 1 & 92.9 \\
\hline 13 & 13 & 12 & 1 & 92.9 \\
\hline Average & 13 & 12 & 1 & 92.9 \\
\hline
\end{tabular}

\begin{tabular}{|c|c|c|c|c|}
\hline Poem & Total number of words & Bedawiet & Arabic & Percentage \\
\hline 14 & 13 & 10 & 3 & 23.1 \\
\hline 15 & 11 & 7 & 4 & 36.4 \\
\hline 16 & 21 & 11 & 10 & 47.6 \\
\hline Average & 15 & 9 & 6 & 35.6 \\
\hline
\end{tabular}

\section{Discussion}

The objective of the study; -"The Role of Traditional Songs in Preserving Languages of Minority”-, was to find ways of reducing languages dying out in the community. This study takes Bedawiet as a case of minority language in Sudan which has been changing due to overlapping with neighboring languages (Adrob, 2013, p. 140).

While statistics display the Beja poems having a very limited number of Arabic words until the $19^{\text {th }}$ Century, a huge change has occurred since the middle of the $20^{\text {th }}$ Century when the first National Sudanese Government was established.

Looking at the Beja songs in the two different periods showed that the processes of examining the Beja songs by a panel in the Beja Club resulted in returning the lexis and style of the Bedawiet language as it was in 1800s. It is observed, from the given examples, that modern songs are replicas born in features of the traditional forms. Therefore, some young Beja writers actively developed literary work on Facebook and they are proud of the language and its prestige.

The committee which was established in Beja Club in Port Sudan had taken some important decisions which mandated further studies in this matter. The research contacted some of those who have already shown a strong interest in promoting the Beja song. They obviously came up with valid opinions to reduce the Arabic words in the Beja songs.

They created a team that collects and reports the work to an assessing panel, which decides the passing or failing poems according to a given criteria before presenting the song to the public. That notion led to a huge decrease of Arabic words in Beja poetry as it was shown in the analytical Table (3).

The influence of the panel on Beja song could have been of a greater impact if it was broadcasted via the local radio or TV to the targeted audiences as well as implementing it in effective schooling programs.

The continuity of the committee of Beja Club could also be sustainable in preserving Bedawiet language if UNESCO organizations hosted the panel. However, the insufficiency of the qualified harmonic team and the negligence of the media have negatively affected the volunteering group. Another major factor led to the disappearance of the neglecting idea was the unwise treatment to the panel especially from the poet and writers from one side and official government from the other side.

In addition, the rich library which is created on the internet to promote the language is not effectively used by Bedawiet speakers. So, drawing children's attention to these websites will be of great value if the poems are well selected. Moreover, the importance of broadcasting is essential as many locals do not have access to the internet.

Surprisingly, the data collected to test the traditional songs and poems for this study assumed that poets competed to produce their work in that period. They attempted important and interesting social topics related to their life. So, having the poets controlled by a panel that checks the validity of their work prior to presenting to the public can be another solution to address the problem of Arabic words in Bedawiet poems.

Nowadays, popular singers who participate with musical bands in weddings; sing traditional songs and they give the sense of bridging the gap between the generations. Young poets such as Osheik who have a clear objective of preserving the Bedawiet language can express their modern message through these singers. It is observed that younger 
people showed interest by deeply involving into musical activities rather than the mature who gives high expectation of accepting this type of songs.

Beja culture does not focus on a unique oral genre that verifies traditional songs and poetry. However, composing history and natural life has allowed Osheik (2012), to write an entire book about the theme of camel. Getting to write about specific topics in different genres indicates rich culture; so the young Bedawiet speaker can learn better and may perform well.

The study also concludes that citizens have influenced much more than other locals as they communicate in Arabic at work or the children studying with their non-Beja mates in schools. Bedawiet has been affected much by parents who live in cities and believe that the language with less modernity and suitability in the $21^{\text {st }}$ Century.

Noticeably, educators are aware of the right time when children appreciate literary work and exactly what to teach them, how and where. However, the popular genres can be well selected from the environmental occasions on which they are fully engaged. Selecting rhyming poems will definitely be appreciated by young learners.

Children enjoy competitions and playing games; therefore, traditional teaching methods of literature cannot be attractive in the stage of reforming a language. However, putting the children in groups and getting them to compete to understand and pronounce the words correctly as well as appreciating the meanings of the verses can create an environment of accepting the language in general, and more specifically, the poetry.

The outdoors annual religion occasions which are attended by approximately 30 thousands of locals in different towns, can be used to allow children opportunities to produce short poems on themes related to these religious celebrations. For example, /hau- li:-ia/ in Sinkat or Sawakin are not the only, but they are the biggest occasions that children attend with their parents. Furthermore, that might raise parents' awareness of the risk that faces their mother language.

Moreover, parents base their assumption on their own experiences without considering the locals who live in areas where only Bedawiet is spoken. They also did not consider that children growing up with unknown culture. Inappropriately, they are not aware of the progress that has been made by people working to maintain parents' language.

Maintaining parents' language must correspond with children's attraction. A very low number of children found speaking Bedawiet in cities was due to the parents who neglected to speak Bedawiet to their children at home. Involving parents in reforming children's language can increase the time they allocate to communicate in the Beja language as well as preparing the children for the competitions.

It is now becoming obvious that preserving and improving languages of minorities is possible through traditional songs and poetry if modern literature is edited by creating reviewing bodies. It is essential to preserve the culture and languages of minorities as they are first taught by parents' which indicate a continuation of natural life.

\section{Conclusion}

The study concludes that citizens have influenced much more than other locals as they communicate in Arabic at work or the children studying with their non-Beja mates in schools. Bedawiet has been affected much by parents who live in cities and believe that the language with less modernity and suitability in the 21 st Century.

\section{Recommendations}

The study, the Role of Poetry in Preserving Languages of Minority in Sudan, is ambitious as it aims to shed a light on the languages of minority, in general, and the Beja language in Sudan in particular. The study found that languages of minorities are at risk and therefore, it recommends protecting them from dying out.

Languages of minority have been examined in different contexts and since the research has started in this language, there have been a non-stop process of borrowing words from Arabic and these words adopted to the Bedawiet grammar, sound and morphological systems and as a results, the words have added to Bedawiet lexicon. (Adrob, 2013).

Governments need to provide teaching materials including the regional languages as an optional subject for nonnatives. The material for the Beja language is available in the Beja Cultural Studies Centre at Red Sea University. It can be graded to young learners.

The Beja language can be translated and taught in earlier levels. It can be included in competitions in annual religious occasions'. Teachers can be trained in the Centre of Beja Cultural Studies at Red Sea to enable parents being actively involved in the tasks. 
Using the Beja language in different academic contexts allows children to learn and familiarize themselves with varieties of favoring methods and techniques of learning the language.

\section{References}

Adrob, H. (2013). Lexicalization of Loanwords in Bedawie Language. Retrieved, November 20, 2020 from http:// search.shamaa.org/FullRecord?ID=112649

Adrob, H. (2020). Phonological changes of Arabic loanwords in Bedawie. SSRN. Retrieved 13/11/2020 from https:// papers.ssrn.com/sol3/papers.cfm?abstract_id=3543361

Beja. (2018) World Directory of Minorities and Indigenous Peoples. Retrieved November, 2020 from https:// minorityrights.org/minorities/beja\#: :text=Beja\%20of\%20the\%20deserts $\% 20$ of,extend $\% 20$ into $\% 20$ Egypt $\% 20$ and $\% 20$ Eritrea

Chauvot, P. (2016). Endangered Languages: Why are so many Languages becoming Extinct? Retrieved, November 10, 2020. https://www.communicaid.com/business-language-courses/blog/why-are-languages-dying/

Dahl, G. (1991). The Attmaan Beja of north-eastern Sudan. Stockholm Studies in Social Anthropology, SSSA in Cooperation with Nordica Africana institute, Uppsala.

Hudson, R. A. 1964. A Grammatical Study of Beja. Boston, Spa: British Library

Martine Vanhove and Mohamed-Tahir Hamid Ahmed (2018). Diminutives and augmentatives in Beja (NorthCushitic). Studies in Language, John Benjamins Publishing, Special issue Morphology and emotions across the worlds languages. Maïa Ponsonnet \& Marine Vuillermet, 42 (1), 51-80.

Morin, D. (1997). Mimetic Traditions in Beja Poetry from Sudan. Research in African Literatures, 28(1), 15-34. Retrieved November 10, 2020, from http://www.jstor.org/stable/3819917

Osheik, A. (2012). The Beja Camels. Dar-el- khulood Press, Khartoum.

UNICEF,(2017). The impact of language policy and practice on childrens learning: Evidence from Eastern and Southern Africa. Retrieved November 11, 2020 from https://www.unicef.org/esaro/UNICEF(2016)LanguageandLearningFullReport(SingleView).pdf

UNHCR(2018). World Directory of Minorities and Indigenous Peoples - Sudan : Beja. Retrieved November, 2020. https://www.refworld.org/docid/49749ca632.html

Wedekind, K and Mohammed, M. (2008), A Beja Saga in four Dialects: Lexical and other Differences. Retrieved November 11, 2020 from https://www.academia.edu/29792565/2008_Klaus_Wedekind_with_ Mahmud_Mohammed_A_Beja_saga_in_four_dialects_Lexical_and_other_differences_In_Gabor_Takacs_ ed_2008_Semito_Hamitic_Festschrift_for_A_B_Dolgopolsky_and_H_Jungraithmayr_Berlin_Reimer_pp_366_378 


\section{Appendix 1}

List of Symbols and Abbreviations

\begin{tabular}{|c|c|c|}
\hline & Name & Example \\
\hline.$n$ & $\begin{array}{l}\text { A marker in Arabic, } \\
\text { indicating an indefinite } \\
\text { noun }\end{array}$ & /?aða:n.n/, \\
\hline$n$ & noun & Bed. /bhr/ n. "sea" \\
\hline sg & singular & /baha:ri:ba/, n. sg., "sailor" \\
\hline pl & plural & /bah'ha:raba/, n. pl., "sailors" \\
\hline f & feminine & Ar. /?a:la.h/, n. sg.f., "instrument" \\
\hline $\mathrm{m}$ & masculine & Ar. /?alma:s/, n.sg.m., 'diamond" \\
\hline itv & intransitive verb & Bed. /faida/, itv. imp, "to derive profit" \\
\hline tv & transitive verb & $\begin{array}{l}\text { Bed. /addba/, tv., "to teach good } \\
\text { manners" }\end{array}$ \\
\hline imp & imperative & $\begin{array}{l}\text { Ar. /?addib/, tv. Imp., "to teach } \\
\text { manners" }\end{array}$ \\
\hline $\operatorname{adj}$ & adjective & Bed./asafari/, adj.," yellow" \\
\hline$\dot{\mathrm{g}}$ & $\dot{\varepsilon}$ & $\begin{array}{l}\text { Ar. /?a:ǵlab/, comp. , " most of, } \\
\text { generally" }\end{array}$ \\
\hline d & 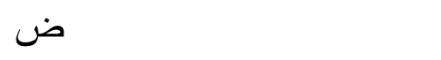 & /?af'đal/, adj.,"better, best, preferable" \\
\hline$\xi, \hat{s}$ & 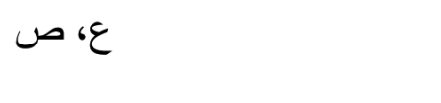 & $\begin{array}{l}\text { Ar. /?al } \xi a \hat{r} / \text {, n. sg.m.," afternoon, } \\
\text { prayer at this time" }\end{array}$ \\
\hline$x$ & $\dot{\tau}$ & Ar. /?alxami:s/, n.sg.m.," Thursday" \\
\hline $\int$ & ش & $\begin{array}{l}\text { Ar. /?a } \iint \mathrm{ir} / \text {, itv.imp., ' to make, indicate, } \\
\text { state, record" }\end{array}$ \\
\hline$\theta$ & ث & $\begin{array}{l}\text { Ar. /?aӨar/, n. sg. pl., " track, sign, } \\
\text { touch, effect, influence" }\end{array}$ \\
\hline $\mathrm{t}^{\prime}$ & b & $\begin{array}{l}\text { Ar. /? idbit'/, tv. imp. ," to grab, tackle, } \\
\text { overcome, to have under control" }\end{array}$ \\
\hline ð & $\dot{j}$ & $\begin{array}{l}\text { Ar. /?iða:a.h/, n. sg. f.," dissemination, } \\
\text { announcement, broadcast" }\end{array}$ \\
\hline$\check{\mathrm{z}}, \mathrm{h}$ & ح' b & $\begin{array}{l}\text { Ar. /?ihfaž/, tv. imp., " to protect, } \\
\text { observe, take acre, save, remember" }\end{array}$ \\
\hline$\zeta$ & ج & $\begin{array}{l}\text { Ar. /? us } \zeta u d /, \text { itv. Imp., "to bow down in } \\
\text { worship, prostrate" }\end{array}$ \\
\hline comp & Comparative & $\begin{array}{l}\text { Ar. /?a:ğlab/, comp. , " most of, } \\
\text { generally" }\end{array}$ \\
\hline d' & Neighbouring /d/ & Bed: /fed'ig/, "four" \\
\hline
\end{tabular}




\section{Appendix 2}

Songs retrieved, 15/11/2020 from https://www.facebook.com/adroobhuaan

$$
\begin{aligned}
& \text { قؤستي مهتيك شُبوتو } \\
& \text { المعنى : } \\
& \text { هذه الغمائم المتوشحة } \\
& \text { في احضان الار اضي المندة المندة }
\end{aligned}
$$

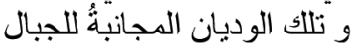

$$
\begin{aligned}
& \text { فذاك خير ان اثروت الارض حتى الصباح } \\
& \text { فال : أوشيك محمد ( ادروب هِوَن ( } \\
& \text { ككوشميب أوبئلوك } \\
& \text { تنيبر فتي مني سور كنامبيب } \\
& \text { رهن سييف لُّلينت مندا } \\
& \text { تيجها دايقات هودنيتي } \\
& \text { المعنى : } \\
& \text { تلك السحب المتز احمة } \\
& \text { و التي تنساب بين ضو البـ القمر الترد } \\
& \text { شعرث بزخات المطر الباردة } \\
& \text { و هي تتمايل كل الجهات بالز عود } \\
& \text { شبو تلك اير هيب إكتي } \\
& \text { شبوكات للإسيني } \\
& \text { اوتلك و هدات هوبيتي } \\
& \text { أودبو كيبدل آيايتي } \\
& \text { المعنى : } \\
& \text { يظهر للك الطيبة حينما يلقاك }
\end{aligned}
$$

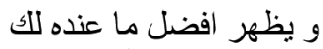

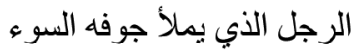

$$
\begin{aligned}
& \text { لا يتغييز مهها كانت صلته بك الك } \\
& \text { أوشيك محمد } \\
& \text { آليا اوسمو ثوبوثيب } \\
& \text { ثبريتيب اتهمداب } \\
& \text { هُمد أوكو اسنايت ديقوت أتهدابت } \\
& \text { لئا ادمي أوريت شفاعايت دئات }
\end{aligned}
$$

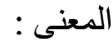

$$
\begin{aligned}
& \text { اغلى ما في الارض : الهن } \\
& \text { و المحمود في السماء الأي } \\
& \text { نبي الله محمد } \\
& \text { شافع ابن ادم بوم القيامة } \\
& \text { دِق آدميث . }
\end{aligned}
$$

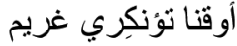

$$
\begin{aligned}
& \text { تسهسيروك ثوبنكاني } \\
& \text { أوتيلال توبنرينيدها } \\
& \text { شوكينهون }
\end{aligned}
$$

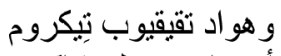

$$
\begin{aligned}
& \text { أو مها توبن تلو شاكوي بويكي } \\
& \text { أوقناو همي دِبنماب تلوني } \\
& \text { الميسئيت رهما رهيمِيني ديني } \\
& \text { في اخر الليل قبل الفجر } \\
& \text { بتسلل الشروق للضياء } \\
& \text { كالقلب المظلم هماً } \\
& \text { يفرح من حيث لا بحتسب المنب } \\
& \text { إشبشبوبي أوشتهوك } \\
& \text { أودايوك للوسيني } \\
& \text { و إلم توتلو سوردباتي } \\
& \text { إكتي أومدهنيب لبابوك } \\
& \text { المعنى : إني } \\
& \text { يُجمل ما تفعلهُ }
\end{aligned}
$$

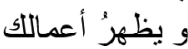

$$
\begin{aligned}
& \text { العلم الذي يتثدمهُ الو عي اعي } \\
& \text { بكون خير ا للك في حباتك } \\
& \text { فدق آدميت ( رباعيات ) } \\
& \text { تودنباتيب تيفيتي }
\end{aligned}
$$

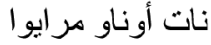

$$
\begin{aligned}
& \text { أورزق ادأدداب أكي } \\
& \text { هنن هسكيب ددابني } \\
& \text { بالحرف اللاتتيني } \\
& \text { من الثعر البجاوي القديم } \\
& \text { السكناب ( فدق ادمبيت ) } \\
& \text { قال : محمد علي ( ابوفاطمة (لمبن ) } \\
& \text { أميلبات أروي نيو } \\
& \text { يأتمر آوفئيب هوديت آنيت } \\
& \text { ايشو قا إيربا ساللين }
\end{aligned}
$$


Appendix 2 (Cont.)

$$
\begin{aligned}
& \text { و تأتي الكراهية من كثرة الاستهزاء }
\end{aligned}
$$

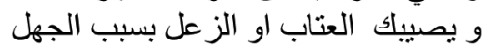

$$
\begin{aligned}
& \text { و تتحصل على الاخلاق و المكارم بمعرفة الاصنول } \\
& \text { نات هينيب رهسوب دوييل } \\
& \text { تشئاي كر ياتا } \\
& \text { إقهور أ با مفياكوك سنكايدها } \\
& \text { تورينوك مهمودي التياكي }
\end{aligned}
$$

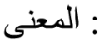

$$
\begin{aligned}
& \text { أن تطلب شيء من الآخرين }
\end{aligned}
$$

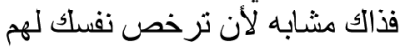

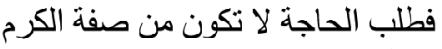

$$
\begin{aligned}
& \text { فالظروف نجبر كت على الحمل الثقليل }
\end{aligned}
$$

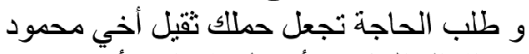

$$
\begin{aligned}
& \text { هن اقو ال الحكيم : أبو علي قو يلائ أور } \\
& \text { أُؤكو اسنا تِرِ هماتِيِو } \\
& \text { أوكثيايور إنيويت } \\
& \text { قودي هيبنين فهي تِتِّرنا } \\
& \text { وريب أوقماي إهيبيت فيتي }
\end{aligned}
$$

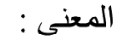

$$
\begin{aligned}
& \text { الرحمة التي ينزلها الخالق لعباده }
\end{aligned}
$$

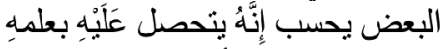

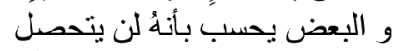

$$
\begin{aligned}
& \text { على تلاك الرحمة او الارزاق لأندُ جاهل }
\end{aligned}
$$

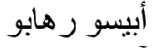

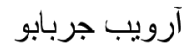

$$
\begin{aligned}
& \text { تودنياو هارويكهن } \\
& \text { توكناو آيبب مسيتني } \\
& \text { المعنى : } \\
& \text { و لقد رأيت بنفسي } \\
& \text { لا تلاتث ور اء الدنيا } \\
& \text { فأنها تأنبك لوحدها } \\
& \text { من الشعر البجاوي القديم } \\
& \text { أوشيك محمد } \\
& \text { فيرمات مو قتتبب } \\
& \text { كتيتيت انو و هربيبي } \\
& \text { تاهدقويت ارور كو ابسات } \\
& \text { اوسيبي اشميبيوك اركر انبرك } \\
& \text { ريش و أويو داياب كالباب } \\
& \text { ادوي براب شابهين } \\
& \text { لالوي شبوب ديري } \\
& \text { إقودييك انشمبييوك } \\
& \text { و ايمهوت و هادوم }
\end{aligned}
$$$$
\text { أوترموما إيسابي إتمرييك : أميك }
$$$$
\text { المعنى : المترميا }
$$$$
\text { لقد يُعَادِي القلبُ ما يكره }
$$

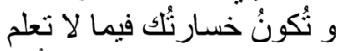

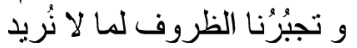$$
\text { فيجب أن نتحلى بالصبر يا عبيسى لئر }
$$$$
\text { أوشيك محمد }
$$$$
\text { عيداً عن ضجيج الو اقع و الأحداث }
$$$$
\text { أودهي دهي شهنا باكابي }
$$$$
\text { لهيثيت بشبيييك }
$$$$
\text { أميثبر ا مهينكا كيسنهو كئو }
$$$$
\text { أوسلف أوبترشيدي أبيني }
$$

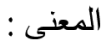

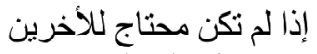$$
\text { و لا لانتظر إلى الو اقع بعين البصيرة }
$$$$
\text { لا لا تنتظرك الأشياء النتي تثمناها }
$$

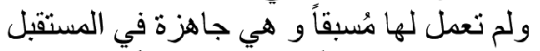$$
\text { من حمم الحكيم : أبو علي قوي جالاي أوري }
$$$$
\text { قلكا أوراو لتسيت هيسي }
$$$$
\text { سهيسي أوقرويو إنيو }
$$$$
\text { يكهوي قيب إقهو ا داقوي }
$$$$
\text { نكي باموشاشيماب إناب }
$$

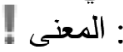

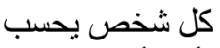$$
\text { بأن رأيه اهم من الآخر }
$$

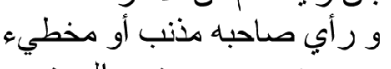

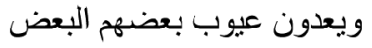$$
\text { مع اعدائهر رغم انهم منقلون }
$$$$
\text { بالعيوب أبران }
$$$$
\text { ونفِس آبريت نوهريويثو }
$$$$
\text { إيتيلل بي سغو سير نييك تيكي }
$$$$
\text { آقتا سقيا تهي آمرو اب }
$$$$
\text { دقي كيكريف أوكو اسنايو }
$$$$
\text { المعي النفوس ما تريدئ }
$$$$
\text { لو لو تخذلهم الظروف }
$$$$
\text { و القلوب المتتشابهة رغم بُعِدها }
$$$$
\text { لا يخيب ظنها الخالق }
$$$$
\text { أوشيك محمد }
$$$$
\text { او مشيش و نقو'دي إكتي }
$$$$
\text { بأنكار تيسوقنتيتي }
$$$$
\text { اوياي اوجلهي دويليوك }
$$$$
\text { اورياً و هبريت كننتي }
$$

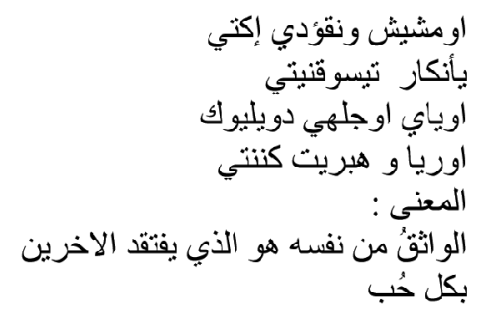


Appendix 2 (Cont.)

بابيا رها فلبلمينت مِندا و إيلبا سؤلا كونيسو المعنى : المبا :

قمةُّة جبل أسوتربا مرورا بمناطق إينباي نتمنى رؤية قطر ات ألمطر المنساقطة و السيول تروي جبل إيلباو بو اديه

$$
\text { دأوشيك محمد }
$$

دي تميسبيروك قيقيدي مهيو دي أوردق إتقيف و إمر دويل أومكر إيديب كوديني

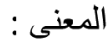

إذا تهربت منك الدنيا لترحل عنك يا محمود يعثر الرزق و يقرب الأجل و ينعام الصواب !ـ! باللغة البجاوية : باترب

tidiyya timeesbiiruuk giigiida mhmuuday uurdig eedgiif wimir dawwiil uumkir eedeeb kwidiini و قال أيضاً :

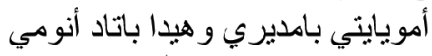
همداب وير تئني شاكيك أوسرهو أقل مديني . المعنى : المنره قبل أن تغضب : من الصديق

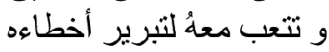
و قوبل أن تر افقه بقلب اخر اخطر مجاملاً له بيتحسن أن تودعه بمحبة

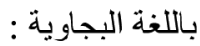
amooyyaatiit baamdeeri whiida baaleed anuumay hamaddb weer ginaay shaakiika wisrha waagil madiini

$$
\begin{aligned}
& \text { المرجع من كتاب : من تأريخ البجا } \\
& \text { المؤلف : المؤرخ : محمد أدروب أو أو هاج } 2008 \\
& \text { الكتاب الأول (( الطبعة الثانية )) } \\
& \text { قلا مِكري مِكر بائدي } \\
& \text { دهريدها هي سكنيبيب } \\
& \text { تهابي تأرواتثو تموقيم }
\end{aligned}
$$

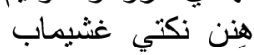

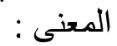

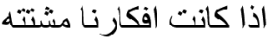

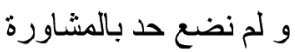

$$
\begin{aligned}
& \text { لكي تكون خطوة لنا للمستقبل }
\end{aligned}
$$

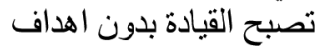

$$
\begin{aligned}
& \text { و نصبح نحن جهلاء دغيبون في و اقعنا }
\end{aligned}
$$

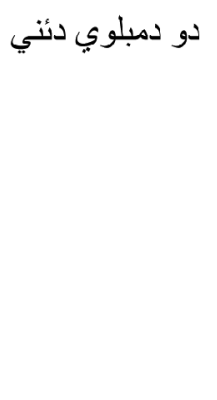

$$
\text { أوراي يدود شابهين }
$$$$
\text { اون اوسي دباب مدلل }
$$$$
\text { تومر ايا شابيهيني }
$$$$
\text { كهي مسكتات بوبي }
$$$$
\text { سوروك اشمبييوك بك }
$$$$
\text { اليلمي يهركا }
$$$$
\text { توليب هوي سساتييك }
$$$$
\text { ادبي مر ات رسما }
$$$$
\text { تنقش الثمبيبيوك اتك }
$$$$
\text { هالفوتشيب اونقا }
$$$$
\text { ارما قدات شنقول }
$$$$
\text { و هي اتقريش تألي }
$$$$
\text { و هيريز انمبيبيوك }
$$

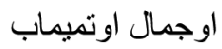

اني منيا باقامييك ارنيكاب

و اتور مني ريائ باكياي

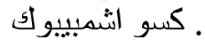

$$
\text { عندما يكون الثباب }
$$

يشعر بالوطنية و بالإنتماء

بالأرض من حوليهِ

و يعرف مقدار ما وضعلهُ الأجداد

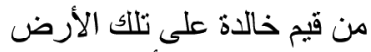

المثبعة من دماء أجدادنا الطاهرة

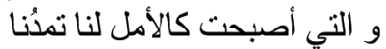

بكل طاقة تفاؤلية للغد و للتمسك لألكائ بهذا الإرث العميق .

سنكون على قدر المسؤلية اتجاه لغتناو عاداتتاو تقالبيناو إرثنا الأصبل

$$
\begin{aligned}
& \text { و هانشو أفقداب باكاي } \\
& \text { هي باديب آشويي } \\
& \text { تيربا للبيكميب أوديش } \\
& \text { إيدب إيبسين بجابتو الإكين } \\
& \text { تمازج الطبيعة مع الباسنكوب } \\
& \text { و الكلمات الوطنية التي تعكس البنس } \\
& \text { روح الانتماء للأر ض و. القو مية الو احدة } \\
& \text { بصوت الثناب المباع : عمر أركه } \\
& \text { النشوق للثنتاء و المطر } \\
& \text { اسوترباي إتقيق } \\
& \text { إيتباي إيتمبتيث }
\end{aligned}
$$




$$
\begin{aligned}
& \text { الثجاعة و الغيرة و الجدية } \\
& \text { لا تأتي بالمال او تخرج بالزشوة } \\
& \text { و لا تكون ور اثة من الاجداد . } \\
& \text { من أقو ال : أركه صدابر } \\
& \text { و هدأ موسى هذه العبيات التأريخية . } \\
& \text { أودار يأنكو نا باكاي } \\
& \text { إيكي بيو افقبنيب } \\
& \text { شبنان أوجنُليناي } \\
& \text { تيمنو قبوتمبنيب } \\
& \text { المعنى : } \\
& \text { هي الارض لن يضحي لأجلها } \\
& \text { غير أصحابها الحقيقين } \\
& \text { انظر الى هذا الرجل و هو } \\
& \text { يرثرقُ دمو عه مخافة الموت } \\
& \text { من التأريخ البجاوي } \\
& \text { اسوترباي و هاشون } \\
& \text { اومه برووت آكيتيت } \\
& \text { أو قنب كو هايما مهيوب } \\
& \text { دهي نيني شئنشيتيت. } \\
& \text { المعنى : } \\
& \text { أرضي و جبل أسوتربا } \\
& \text { الذي نكونُ في شر قهـ مدينة بورتسودان } \\
& \text { مناطقُ القُبب عندما نُصبحُح رطبةً جافة } \\
& \text { نئُُ لها شوقاً و ذكريات . }
\end{aligned}
$$

Appendix 2 (Cont.)

$$
\begin{aligned}
& \text { الفنان : محمد البدري و الزمن الجميل }
\end{aligned}
$$

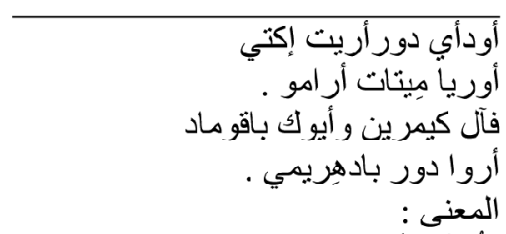

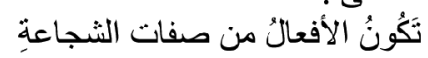

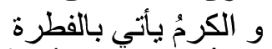

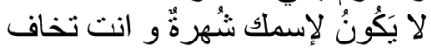

$$
\begin{aligned}
& \text { على ها في بديك لإنك }
\end{aligned}
$$

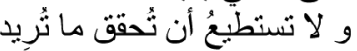

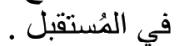

$$
\begin{aligned}
& \text { و انت تخافُ من الواقع . } \\
& \text { أوترموماوا و إيتاروا } \\
& \text { هيدا إمنقد شمامتيوا }
\end{aligned}
$$

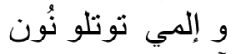

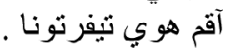

$$
\begin{aligned}
& \text { المعنى : الموي } \\
& \text { الصبر و وقوة التحمل }
\end{aligned}
$$

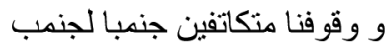

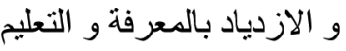

$$
\begin{aligned}
& \text { لا اعلم مخرجا مما نحن فيه غير هذانيم }
\end{aligned}
$$

من الثـعر البجاوي القديم ثودايناي ثوريهوب

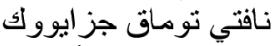
تونثبو بثمهليب أوتلك ائك

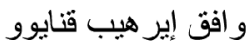

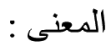

إذا عاملث الآخر ين معاملة حسنة و ردو للك بأفعال و أقو ال مسيئة

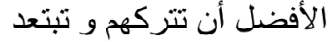

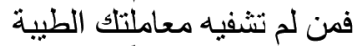

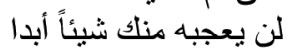

$$
\begin{aligned}
& \text { ابتعدو ا عن الاساءة مهما نطلب الأمر }
\end{aligned}
$$

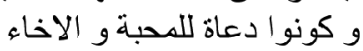

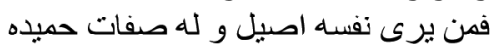

و لا من من شيمنا التي اكتسبناها من اباءنا

$$
\text { نرؤلي قرشيت كري كتأكي }
$$


Appendix 2 (Cont.)

$$
\begin{aligned}
& \text { فأرجو أن لا تنسى فضلهُ عليك } \\
& \text { آر اتيك إيتيدها } \\
& \text { باهريو بتكلاسيك } \\
& \text { تومرمام مجابر ات هريو } \\
& \text { تر و فايدي مشو داب } \\
& \text { المعنى : } \\
& \text { إذا لم تستطع التفاهم مع صديقك } \\
& \text { و لم تسنطع ان تميل إلى ما يريده } \\
& \text { فحق الصداقة إما أن تجامله } \\
& \text { أو تفار قهُ بإبتسامـِة لأجل الود ـ } \\
& \text { من الشعر البجاوب القديم } \\
& \text { الثاعر : قو يلاي أور } \\
& \text { و سلها دايي و هماد كيمري } \\
& \text { أوفنا كوِن قؤدمبا } \\
& \text { أوتلك و إلميب هور كيمري } \\
& \text { أو دبيب قهواب إيير ييلك } \\
& \text { المعنى : } \\
& \text { لا يلقى الشكر و الثناء حتى لو عمل حسناً } \\
& \text { و لا يكون مسثنياً من الخلافات } \\
& \text { فالرجل لن يلقى أصحاباً و تابعين في العلم } \\
& \text { إذا كان عيبةُ الأخلاق } \\
& \text { من الثعر البجاوي القديم } \\
& \text { الشاعر : علي هوجر }
\end{aligned}
$$

$$
\begin{aligned}
& \text { أونشيك مصمد } \\
& \text { مويايتي بافجئي } \\
& \text { هيدا باتاد آنومي } \\
& \text { همداب ويرقنى شاكيكا } \\
& \text { آوسر ها و اقل مديني } \\
& \text { المعنىى : } \\
& \text { قبل الزعل الغير متوقع } \\
& \text { و التو اصل بدون جدوى } \\
& \text { الصديق الذي تشتمرُ معهُ مجاملة } \\
& \text { الأفضل أن تبتعد عنهُ بعقلانية } \\
& \text { من الثعر البجاوي القديم } \\
& \text { الثـاعر : آلميني أور } \\
& \text { تودايناي إوريوك اوتلك } \\
& \text { توشبو بامق دبيسي } \\
& \text { مدا إتمريب كيكي } \\
& \text { إير هيب رياسميوك }
\end{aligned}
$$

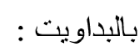

Too dainay iiuryok uutak

Tooshbu ba maak dabiisay

Mdaa iitmreeb kiiky Iirheeb ryasmyook .

$$
\begin{aligned}
& \text { المعنى : } \\
& \text { الثخص الذب بعاملك بالطيبة } \\
& \text { دو ن أن يشعر كك بأنه يعاملك بها } \\
& \text { و بمد للك الكرم حيث بر اك } \\
& \text { ذاك هو الشخص النادر في هذه الحياة }
\end{aligned}
$$

Cite this article as: Hassan Ali Adrob (2021). The role of traditional songs in preserving languages of minority: The Beja case in Sudan. International J ournal of Languages and Culture. 1(1), 18-37. doi:10.51483/ IJ LC.1.1.2021.18-37. 